\title{
The Relation of Age and Parity with the Incidence of Hypermesis Gravidarum in Pregnant Woman in Dr. H. Moch Ansari Saleh Banjarmasin Hospital
}

\author{
Susanti Suhartat ${ }^{1}$, Nita Hestiyana ${ }^{2}$ \\ \{nitahestiyana@unism.ac.id\} \\ Sari Mulia University, Jl. Scout 2, Pemurus Affairs. District. East Banjarmasin, \\ Banjarmasin, South Kalimantan, 70238, Indonesia
}

\begin{abstract}
Hypermesis gravidarum is a problem that is often found in pregnant women. According to $\mathrm{WHO}$, the incidence of hypermesis gravidarum reached $12.5 \%$. in Indonesia pregnant women with hypermesis gravidarum reach $14.8 \%$. Analyzing the relationship of age and parity and incidence of hypermesis gravidarum in pregnant women at Dr.H.Moch Ansari Saleh Banjarmasin Hospital in. The design of this study uses analytic surveys by case-control. The sampling technique is systematic random sampling with the number of subjects studied consisting of 43 cases and 86 controls. The results showed that there was a correlation between age and the incidence of hyperemesis gravidarum in pregnant women is ( $\mathrm{p} 0.00 ; \mathrm{OR}=5.6)$ and there was a correlation between parity and incidence of hyperemesis gravidarum in pregnant women is $(\mathrm{p} 0.00 ; \mathrm{OR}=7.2$. There is a relationship between age and the incidence of hyperemesis gravidarum where pregnant women aged 20-35 years are at higher risk of experiencing hyperemesis gravidarum compared with pregnant women aged $<20$ and $>35$ years and there is a relationship between parity and the incidence of hyperemesis gravidarum in pregnant women where nullipara mothers are more at risk of hyperemesis gravidarum.
\end{abstract}

Keywords: Age, Parity, Hyperemesis Gravidarum

\section{Introduction}

Pregnancy complications one of which is nausea and vomiting or known as hyperemesis gravidarum. Nausea and vomiting are common diseases among pregnant women. levels of nausea and throwing from mild to severe illness that required persistent and excessive throwing [1]. Some other obstetric conditions such as hydatidiform mole and gamelli also have a high risk for the occurrence of hyperemisis gravidarum due to high levels of pregnancy hormones namely Human Chorionic Gonadotropin (HCG) [2]. Nausea and vomiting are common in early pregnancy. Nausea and vomiting usually occur in the morning, therefore it is also called morning sicknes. Pregnant mothers who experience nausea and vomiting can become hyperemesis gravidarum. About $50-60 \%$ of pregnancies are accompanied by nausea and vomiting, out of 360 pregnant women, around $2 \%$ experience nausea and vomiting in the morning and around $80 \%$ experience nausea and vomiting throughout the day. This condition usually lasts and reaches its peak at the age of 9 weeks. However, about $20 \%$ of cases of nausea and vomiting will continue until birth [2]. Visits of pregnant women examinations in Indonesia obtained data on mothers with hyperemesis gravidarum reaching $14.8 \%$ of all pregnancies. The incidence of hyperemesis gravidarum in Indonesia is estimated that $10 \%$ of pregnant women experience hyperemesis gravidarum, as many as 2,203 pregnancies have hyperemesis 
gravidarum [3]. The consequences of hyperemesis gravidarum can cause significant maternal and fetal complications if left untreated [1].

This condition occurs in $69-80 \%$ primigravida, and $40-60 \%$ multigravida. Maternal age $<20$ and $>35$ years are more at risk of the occurrence of hyperemesis gravidarum compared with maternal age 20-35 years. [4]. These extreme cases, can cause death in the mother and fetus due to metabolic changes that persist [5]. Based on preliminary studies that have been conducted by researchers at Dr. H. Moch. Ansari Saleh Banjarmasin, there were 4,875 pregnant women visiting in 2015, and in 2016 there were 5,178 pregnant women. Pregnant women who experienced hyperemesis gravidarum in 2014 were 7 people in 2015 as many as 17 people and in 2016 there were 37 pregnant women. This shows that an increase in pregnant women who experience hyperemesis gravidarum. Based on the problem above, the author is interested in taking the title "The Relation of Age and Parity with the incidence of hypermesis gravidarum in pregnant woman in Dr. H. Moch Ansari Saleh Banjarmasin Hospital.

\section{Method}

This research uses analytical survey method with case control design which is a research design with sampling divided into two groups, there are case samples and control samples. The population in this study were all pregnant women who visited her for a pregnancy check up at Dr. H. Moch Ansari Saleh Banjarmasin in 2016 there were 5,178 pregnant women. In this study, the case sample was a mother who had hyperemesis gravidarum with a total of 37 cases using a sampling technique that is total sampling. While the control sample was pregnant women who did not experience hyperemesis gravidarum, amounting to 74 pregnant women using a sampling technique that is systematic random sampling. Control sampling in this study uses a ratio of $1: 2$ from cases. So that the overall sample is 111 people. The source of the data used in this study is to use secondary data, that is the data obtained is not directly from the research object, which is obtained from the data register of visits of pregnant women, while processing data using the chi square test.

\section{Result}

\subsection{Univariate Analysis}

Characteristics of Respondents by Age

Table 1. Distribusi Frequency respondent by Age

\begin{tabular}{lccc}
\hline No & Category & Frequency & Persentase (\%) \\
\hline 1 & $\begin{array}{c}\text { Risk } \\
(<25 \text { and }>35)\end{array}$ & 18 & $16,2 \%$ \\
2 & $\begin{array}{c}\text { No Risk } \\
(25-35)\end{array}$ & 93 & $83,8 \%$ \\
\hline & Total & 111 & $100 \%$ \\
\hline
\end{tabular}


Based on table 1 it can be seen that of the total 111 respondents, the most age category is pregnant women (20-35 years) as many as 93 people (83.8\%) who are at risk of hyperemesis gravidarum.

Characteristics Respondent Of Parity

Table 2. Distribusi Frequency Respondent of Parity

\begin{tabular}{cccc}
\hline No & Category & Frequency & Persentase (\%) \\
\hline 1 & Risk ( Nulliparous \& Primiparous ) & 79 & $71,2 \%$ \\
2 & $\begin{array}{c}\text { No Risk ( Multiparous \& } \\
\text { Grandemultiparous ) }\end{array}$ & 32 & $28,8 \%$ \\
\hline & Total & 111 & $100 \%$ \\
\hline
\end{tabular}

Based on table 2 it was shown that from a total respondents totaling of 111 respondents, the majority of respondents based on parity are nulliparous and primiparous (a woman who has never given birth to a baby / child and women who have given birth to a live baby for the first time) as many as 79 people (71.2\%).

Cases of hyperemesis gravidarum

Table 3. Distribusi Frekuensi Respondent Hyperemesis Gravidarum

\begin{tabular}{cccc}
\hline No & Category & Frequency & Persentase (\%) \\
\hline 1 & Hyperemesis & 37 & $33,3 \%$ \\
2 & Not Hyperemesis & 74 & $66,7 \%$ \\
\hline & Total & 111 & $100 \%$ \\
\hline
\end{tabular}

Based on table 3 it was shown that the incidence of hyperemesis gravidarum) in pregnant women in Dr. H. Moch Ansari Saleh in 2016 numbered 37 women (33.3\%).

\subsection{Analysis of Bivariat}

Relationship between age and the incidence of hyperemesis gravidarum in pregnant women. 
Table 4. Analysis of the relationship of age with the incidence of hyperemesis gravidarum

\begin{tabular}{|c|c|c|c|c|c|c|c|c|c|}
\hline \multirow{3}{*}{ No } & \multirow{3}{*}{ Age } & \multicolumn{4}{|c|}{ Hyperemesis Gravidarum } & \multirow{3}{*}{ Total } & \multirow{3}{*}{$\%$} & \multirow{3}{*}{ P Value } & \multirow{3}{*}{ OR } \\
\hline & & \multicolumn{2}{|c|}{ Yes } & \multicolumn{2}{|c|}{ No } & & & & \\
\hline & & Frequency & $\%$ & Frequency & $\%$ & & & & \\
\hline 1 & $\begin{array}{c}\text { Risk } \\
(<20 \&>35)\end{array}$ & 12 & 32,4 & 6 & 33,3 & 18 & 16,2 & \multirow{2}{*}{0,003} & \multirow{2}{*}{5,440} \\
\hline 2 & $\begin{array}{c}\text { No Risk (20\& } \\
35) \\
\end{array}$ & 25 & 67,6 & 68 & 73,1 & 93 & 83,8 & & \\
\hline & Total & 37 & 100 & 74 & 100 & 111 & 100 & & \\
\hline
\end{tabular}

Based on table 4, it was shown that from the total of 111 respondents, it was found that the age of mothers who were not at risk (20-35 years) had more hyperemesis gravidarum events, as many as 25 people $(67.6 \%)$, compared to the age at risk $(<20$ and $>35$ years $)$ as many as 12 people $(32.4 \%)$, for age control ( $<20$ and $>35$ years) as many as 6 people $(33.3 \%)$, and age (20-35 years) as many as 68 women $(73,1 \%)$. So it can be seen that the results of the chi square analysis test obtained $\mathrm{p}$ value $=0.003<0.05, \mathrm{OR}=5.440(1.844$ 16.050). It can be concluded that there is a relationship between age and the incidence of hyperemesis gravidarum where pregnant women aged 20-35 years are 5.4 times more at risk of experiencing hyperemesis gravidarum compared with pregnant women aged $<20$ and $>35$ years.

Relationship of parity with the incidence of hyperemesis gravidarum in pregnant

Table 5. Analysis of the relationship of parity with the incidence of hyperemesis gravidarum

\begin{tabular}{|c|c|c|c|c|c|c|c|c|c|}
\hline \multirow{3}{*}{ No } & \multirow{3}{*}{ Parity } & \multicolumn{4}{|c|}{ Hyperemesis Gravidarum } & \multirow{3}{*}{ Total } & \multirow{3}{*}{$\%$} & \multirow{3}{*}{ P Value } & \multirow{3}{*}{ OR } \\
\hline & & \multicolumn{2}{|c|}{ Yes } & \multicolumn{2}{|c|}{ No } & & & & \\
\hline & & Frequency & $\%$ & Frequency & $\%$ & & & & \\
\hline 1 & $\begin{array}{c}\text { Risk } \\
\text { (Nulliparous \& } \\
\text { Primiparous) } \\
\end{array}$ & 34 & 91,9 & 45 & 60,8 & 79 & 71,2 & & \\
\hline 2 & $\begin{array}{c}\text { No Risk } \\
\text { (Multiparous \& } \\
\text { Grandemultiparous) } \\
\end{array}$ & 3 & 8,1 & 29 & 39,2 & 32 & 28,8 & 0,001 & 7,304 \\
\hline & Total & 37 & 100 & 74 & 100 & 111 & 100 & & \\
\hline
\end{tabular}

Based on table 5 it can be seen that of the total 111 respondents, the most hyperemetic category is risk parity (nulliparous and primiparous) as many as 34 people (91.9\%), then parity that is not at risk (multiparous and grandemultiparous) as many as 3 people $(8.1 \%)$, for control parity at risk (nulliparous and primiparous) as many as 45 people $(60.8 \%)$, and parity that is not at risk (multiparous and grandemultiparous) as many as 29 people $(39.2 \%)$. So it can be seen that the results of the chi square analysis test obtained $\mathrm{p}$ value $=0.001<0.05, \mathrm{OR}=7.304(2,052-25,991)$. It can be concluded that there is a relationship between parity and the incidence of hyperemesis gravidarum in pregnant women where parity is at risk (nulliparous and primiparous) 7.3 times more at risk of experiencing hyperemesis gravidarum compared with parity that is not at risk (multipara and grandemultipara). 


\section{Discussion}

\subsection{Analysis of univariate}

Based on the results of research that has been conducted at Dr. H. Moch Ansari Saleh Banjarmasin with a sample of 111 pregnant women in 2016. There were 37 pregnant women who experienced hyperemesis gravidarum as a sample of cases using a total sampling technique, and as many as 74 pregnant women who were used as control samples using a sampling technique that is systematic random sampling with a ratio of 1: 2 so the number of samples is 111 .

a. Age

Results of the frequency distribution of the age of pregnant women in Dr. H. Moch Ansari Saleh Banjarmasin, in table 1 it was found that the highest number of pregnant women who were not at risk where the age of pregnant women between (20-35 years old) were 93 people (83.8\%), compared to pregnant women who were at risk where the age of pregnant women between ( $<20$ and $>35$ years) of 18 people (16.2\%), differs from research conducted by Mullin PM et al (2012) hyperemesis gravidarum more common in young mothers and young pregnant women also has a risk of prolonged disease duration of more than 27 weeks of gestation [ 6 ]

b. Parity

Results of the frequency distribution of parity of pregnant women at Dr. H. Moch Ansari Saleh Banjarmasin hospital, in table 2 most respondents were based on parity, namely nulliparous and primipara (a woman who had never given birth to a baby / child and women who had given birth to a live baby for the first time) as many as 79 people $(71.2 \%)$, compared with pregnant women who are included in the category of not at risk multipara and grandemultipara (A woman who had given birth to live babies 2 to 3 times) as many as 32 people $(28.8 \%)$. Nulliparous has higher risk because of having higher serum and urinary estrogen levels than multiparous women and those women in their first pregnancies have higher first-trimester estrogen levels than in subsequent pregnancies [7]

c. Hiperemesis Gravidarum

Results of the frequency distribution with the incidence of hyperemesis gravidarum in pregnant women in Dr. H. Moch Ansari Saleh Banjarmasin, in table 3 it was found that the most pregnant women who did not experience hyperemesis gravidarum were 74 people (66.7\%), compared to pregnant women who experienced hyperemesis gravidarum which was 37 people (33.3\%).

\subsection{Analysis of Bivariate}

a. Relationship between Age and Hyperemesis Gravidarum

Based on table 4, the largest percentage is in the age category of 20-35 years as many as 93 people $(83.3 \%)$, then aged $<20$ and $>35$ years as many as 18 people $(16.2 \%)$. From the results of research that experienced the occurrence of hyperemesis gravidarum more often at the age of $20-35$ years, as many as 25 people (67.6\%), than 
mothers aged $<20$ and $>35$ years, as many as 12 people $(32.4 \%)$. Based on the analysis test results using chi square obtained $\mathrm{p}$ value $=0.003<0.05$, OR $=5.440(1.844$ 16.050). It can be concluded that there is a relationship between age and the incidence of hyperemesis gravidarum where pregnant women aged 20-35 years are 5.4 times the risk of experiencing hyperemesis gravidarum compared with pregnant women aged $<20$ and $>35$ years.

According to research by Butu (2019) there is a relationship between the incidence of hyperemesis gravidarum at age with the occurrence of hyperemesis gravidarum [8]. This research is in line with Ruri research (2011), entitled "The Relationship between Mother's Age and the Occurrence of Hyperemesis Gravidarum in Adjidarmo Hospital Rangkasibitung in 2011" shows that there is a relationship between age and the incidence of hyperemesis gravidarum with a value of $p=0,000$, this is due to the appropriate age. and can accept pregnancy because of physical maturity and other organs can still be influenced by psychological factors because most likely mothers who refuse pregnancy, fear of losing work, fractured relationships with her husband and other allegations can be factor in the occurrence of hyperemesis gravidarum [9].

b. Relationship between Parity and Hyperemesis Gravidarum

Based on table 5 it can be seen that of the total 111 respondents, the highest category experienced hyperemesis gravidarum, namely parity at risk (nullipara and primipara) as many as 34 people $(91.9 \%)$, then parity that was not at risk (multipara and grandemultipara) as many as 3 people $(8.1 \%)$, for control parity at risk (nulliparous and primiparous) as many as 45 people $(60.8 \%)$, and parity that is not at risk (multiparous and grandemultiparous) as many as 29 people $(39.2 \%)$. So it can be seen that the results of the chi square analysis test obtained $\mathrm{p}$ value $=0.001<0.05$, $\mathrm{OR}=7.304$ (2.052-25.991). It can be concluded that there is a relationship between parity and the incidence of hyperemesis gravidarum in pregnant women where nulliparous mothers are 7.3 times more at risk of experiencing hyperemesis gravidarum.

This study is in line with Oktavia research (2016), entitled "The Occurrence of Hyperemesis Gravidarum Judging from the Distance of Pregnancy and Parity" shows that there is a relationship between parity and the incidence of hyperemesis gravidarum with $\mathrm{p}$ values $=0,000$, this is because in nullipara there is no readiness physically to accept the growth and development of the fetus in her womb in other words in nullipara there is no experience of childbirth so that it has not been able to adapt to changes that occur during pregnancy starting from changes in organs, hormones[10].

\section{Conclusion}

There is a relationship between age and the incidence of hyperemesis gravidarum where pregnant women aged 20-35 years are at higher risk of experiencing hyperemesis gravidarum compared with pregnant women aged $<20$ and $>35$ years and there is a relationship between parity and the incidence of hyperemesis gravidarum in pregnant women where nullipara mothers are more at risk of hyperemesis gravidarum. 


\section{References}

[1] Fell DB, et al. Risk factors for hyperemesis gravidarum requiring hospital admission during pregnancy. Obstetrics \& Gynecology. 107(2):277-284. (2006).

[2] Fauziah. Keperawatan Maternitas Kehamilan. Jakarta: Kencana Prenada Media Group. (2012).

[3] Departemen Kesehatan Republik Indonesia. Laporan Nasional Riset Kesehatan Dasar. Jakarta: Pusat Penelitian Pengembangan Kesehatan. (2013).

[4] Armilah. Hubungan Umur Ibu Dan Pekerjaan Tehadap Kejadian Hiperemesis Gravidarum Di RS Islam Kustati Surakarta Tahun 2009. Jurnal Involusi Kebidanan 2 (40 [internet]. Tersedia pada: www.ejournal.stikesmukla.ac.id. (2010).

[5] Bobak. Buku Ajar Keperawatan Maternitas edisi 4. Jakarta: EGC. (2005).

[6] Mullin PM et al. Risk factors, treatments, and outcomes associated with prolonged hyperemesis gravidarum. J Matern Fetal Neonatal Med 25: 632-636. (2012).

[7] Lee NM, Saha S. Nausea and vomiting of pregnancy. Gastroenterol Clin North Am. (2011).

[8] Butu, Yosepina Otma et al. Faktor-faktor yang Berhubungan Dengan Kejadian Hiperemesis Gravidarum Pada Ibu Hamil Trimester I. eJournal Keperawatan (e-Kp). Volume 7. No 2. (2019).

[9] Ruri and Nurul. Hubungan Paritas Dan Umur Ibu Dengan Kejadian Hyperemesis Gravidarum Di RSUD Adjidarmo Rangkasibitung. Jurnal Obstretika Scientia. Volume 2. No 1. (2011).

[10] Oktavia Lina. Kejadian Hyperemesis Gravidarum Ditinjau Dari Jarak Kehamilan Dan Paritas Di RSUD Dr. Ibnu Sutowo Baturaja Tahun 2015. Jurnal Ilmu Kesehatan Aisyah. Volume 1. No 2. (2016). 